\title{
Dinamika Kurikulum Madrasah Berbasis Pesantren Pada Abad Ke 20 (Analisis Historis Implementasi Kurikulum Madrasah)
}

\author{
Amin Maghfuri \\ Universitas Islam Negeri Sunan Kalijaga Yogyakarta \\ aminmaghfuri@yahoo.com \\ Rasmuin \\ Universitas Islam Negeri Maulana Malik Ibrahim Malang \\ muin@uin-malang.ac.id
}

\begin{abstract}
Madrasa is an Islamic educational institutions that play a role in realizing national education goals. But in its history, the existence of madrassas has experienced complex dynamics and tides. This study was intended to analyze the dynamics and the development of the implementation of the madrasa curriculum, especially those based on Islamic boarding schools in the 20th century. The approach used in this study is a qualitative approach using the documentation method. The results showed that the curriculum dynamics of pesantren-based madrasas in their history experienced various dynamics that could be classified into three groups, namely periods of growth, periods of development, periods of strengthening of existence. The growth period starts from the birth of madrassas from the pesantren's womb and curricula that are dominated by religious knowledge and tend not to be neatly structured. The development periods are characterized by many of fluctuations and tugging on the implementation of the madrasah curriculum mainly because it is related to recognition and existence. The period of strengthening existence began when the existence of madrassas was legally recognized, especially after the issuance of three Ministerial Decrees which emphasized improving the quality of madrasab education.
\end{abstract}

Keywords: Madrasah, Curriculum, Islamic Education

Abstrak : Madrasah merupakan lembaga pendidikan Islam yang ikut berperan dalam mewujudkan tujuan pendidikan nasional. Namun dalam sejarahnya, keberadaan madrasah mengalami dinamika dan pasang-surut yang cukup kompleks. Penelitian ini dimaksudkan untuk menaganalisis dinamika dan perkembangan implementasi kurikulum madrasah terutama yang berbasis pesantren pada abad ke-20. Pendekatan yang digunakan dalam penelitian ini adalab pendekatan kualitatif dengan menggunakan metode dokumentasi. Hasil penelitian menunjukkan bahwa dinamika kurikulum madrasab berbasis pesantren dalam sejarahnya mengalami berbagai dinamika yang dapat diklasifikasikan ke dalam tiga kelompok, yaitu periode pertumbuban, periode perkembangan, periode penguatan eksistensi. Periode pertumbuban dimulai dari labirnya madrasah-madrasah dari rahim pesantren dan kurikulum yang dipakai dominasi oleh pengetabuan agama dan cenderung belum terstruktur rapi. Periode perkembangan banyak ditandai dengan fluktuasi dan tarik ulurnya implementasi kurikulum madrasah terutama karena terkait dengan pengakuan dan eksistensi. Periode penguatan eksistensi dimulai ketika eksistensi madrasah diakui secara legal terutama setelah keluarnya SKB tiga Menteri yang menekankan peningkatan mutu pendidikan madrasah.

Kata Kunci : Madrasah, Kurikulum, Pendidikan Islam

\section{Pendahuluan}

Dalam belantara dunia pendidikan Indonesia, keikutsertaan madrasah dalam mewarnai pendidikan Indonesia sangatlah kental. Madrasah bahkan dapat dikatakan sebagai basis pendidikan bagi masyarakat pribumi dari kalangan bawah. Madrasah banyak diminati karena merupakan anakan dari pesantren, dan umumnya masih berkaitan dengan pesantren. Keberadaannya memberikan dampak yang besar bagi alur pendidikan di Indonesia, terutama dalam rangka mengurangi pengaruh penjajah Belanda melalui sekolah yang dibangunnya. Pengaruh madrasah ini bahkan sudah nampak sebelum kemerdekaan bangsa Indonesia diraih pada tahun $1945 \mathrm{M}$. 
Madrasah di Indonesia diyakini mulai bermunculan pada awal abad ke-20 karena beberapa faktor, salah satunya sebagai respon terhadap kebijakan pendidikan yang diterapkan oleh Belanda. Lahir dalam kondisi sosial-politik yang dapat dikatakan kurang menguntungkan membuat madrasah harus melewati berbagai kondisi sosial-politik yang tidak stabil dan berubah-ubah, namun madrasah tetap mampu tampil sebagai lembaga pendidikan Islam yang mempertegas garis perbedaan dengan pendidikan Belanda pada masa tersebut. Keberadaan madrasah cukup dinamis dan fleksibel dalam menyesuaikan diri dengan konteks sosial-politik dan tuntutan masyarakat pada masa itu, sehingga madrasah mampu tetap bertahan dengan prinsip dan tujuannya.

Dinamika yang dialami madrasah tidak selesai begitu saja setalah kemerdekaan Indonesia diraih. Madrasah tetap harus memperjuangkan tempatnya dalam belantara dunia pendidikan di Indonesia. Hal ini tidak lain disebabkan karena kondisi sosial-politik pasca-kemerdekaan tidak seketika berubah dari periode sebelumnya. Ditambah lagi, stigma yang telah tertanam dan seolah menjadi dogma dalam kalangan masyarakat tentang "pertentangan" antara sekolah umum model Belanda dengan madrasah. Dalam kondisi yang demikian, posisi madrasah cenderung dirugikan terutama dalam upaya pengembangan pendidikan Indonesia yang seolah ingin meminggirkan peran madrasah. Pada periode selanjutnya madrasah bahkan hendak di"sekolah umumkan" dengan adanya peraturan yang mengatur tentang penyatuan tanggung jawab pendidikan pada satu departemen khusus.

Namun sejarah telah mencatat, madrasah tetap eksist dan bahkan berkembang sampai sekarang - yang barangkali berada diluar dugaan banyak kalangan. Hal ini membuktikan betapa kuatnya daya tahan madrasah terhadap berbagai dinamika dan kondisi sosial-politik yang berlangsung. Terlebih lagi, madrasah tidak selalu berada pada posisi yang menguntungkan, atau berada pada pihak penentu kebijakan. Hal tersebut tentunya tidak terjadi begitu saja, malainkan karena fleksibilitas madrasah dalam beberapa hal, salah satunya pada aspek kurikulum. Karena diakui atau tidak, kurikulum merupakan tuntutan dan daya tarik tersendiri bagi yang hendak mempercayakan putra-putrinya pada suatu lembaga pendidikan, dan tuntutan ini agaknya dapat dipenuhi oleh madrasah.

Sepanjang abad ke-20, telah terjadi berbagai dinamika dan perubahan kondisi sosial-politik di Indonesia. Pada periode ini, kurikulum madrasah diuji fleksibilitasnya dalam mengikuti dinamika yang terjadi. Ujian tersebut dapat kita lihat jawabannya sekarang dengan tetap eksistnya madrasah dalam dunia pendidikan Indonesia. Penyesuaian-penyesuaian yang terjadi dalam kurikulum madrasah pada abad ke-20 ini menjadi suatu yang menarik untuk dikaji, terutama untuk mengetahui nilai historis dari dinamika yang terjadi dalam madrasah. Oleh karenanya, dalam makalah ini dipilih judul dinamika kurikulum madrasah berbasis pesantren pada abad ke-20. 


\section{Madrasah Berbasis Pesantren Dalam Tinjauan Historis}

Dalam diskursus pendidikan Islam, kata madrasah sebenarnya bukanlah sesuatu yang aneh untuk menyebut suatu lembaga pendidikan. Kata madrasah merupakan bentuk bahasa Arab yang apabila diartikan ke dalam bahasa Indonesia memiliki arti sekolah. Dalam dunia Islam, menyebut madrasah untuk menunjuk suatu lembaga pendidikan layaknya sekolah - di Indonesia - sama halnya seperti menyebut lembaga pendidikan dengan bahasa Inggris, school. Secara sekilas, tidak ada perbedaan berarti ketika menyebut sekolah baik dalam bahasa Arab maupun bahasa Inggris. Baik madrasah (dalam bahasa Arab) maupun school (dalam bahasa inggris) bila diterjemahkan ke dalam bahasa Indonesia memiliki makna yang sama, yaitu sekolah.

Istilah madrasah merupakan satu bagian penting yang tidak bisa dilepaskan dari pembahasan tentang pendidikan Islam. Keberadaannya sudah mengakar dan menjadi istilah khas Islam yang menunjukkan suatu lembaga pendidikan sejak sekian lama. Istilah tersebut ikut tersebar seiring meluasnya pengaruh Islam di belahan dunia, termasuk sampai di Indonesia. Sebagai negara mayoritas muslim, Indonesia juga tidak lepas dari penggunaan istilah madrasah untuk menunjukkan sebuah lembaga pendidikan Islam. Namun demikian, terdapat beberapa perbedaan maksud dalam penyebutan istilah madrasah di Indonesia jika dibandingkan dengan penyebutan istilah tersebut di tempat lain.

Jika kita mengupas akar kesejarahan madrasah sebagai lembaga pendidikan Islam, maka kita harus kembali melihat sejarah masa lalu dimana kata madrasah pertama kali dipakai untuk menunjukkan suatu lembaga pendidikan, begitu juga perkembangannya. Memang benar bahwa pendidikan Islam sudah dimulai sejak lahirnya Islam yang dibawa oleh Nabi Muhammad SAW, namun sistem yang digunakan masih sangat sederhana. Pada awal masa Islam tersebut, masjid merupakan tempat sentral untuk melakukan kegiatan dakwah dan pendidikan. Sistem yang sangat sederhana tersebut terus berkembang mengikuti dinamika yang ada, sampai muncullah istilah madrasah untuk menunjukkan lembaga atau sistem pendidikan Islam yang dipelopori pada masa Bani Saljuk.

Pada abad pertengahan, Nizam al-Mulk yang merupakan Wazir Bani Saljuk mendirikan madrasah Nidzamiyah di Baghdad. Madrasah ini merupakan lembaga pendidikan yang bertujuan menyebarkan pemikiran Sunni untuk menghadapi tantangan pemikiran Syiah serta untuk menyediakan pengajarpengajar di kalangan Sunni. Pada masa itu, bentuk dan sistem yang kemudian disebut dengan madrasah ini menjadi trend yang hampir seluruh wilayah Islam menggunakannya. Bentuk madrasah ini merupakan hasil dari berbagai dinamika yang dilalui oleh sistem pendidikan Islam yang dimulai dari masjid, masjid khan, 
hingga kemudian muncul madrasah. ${ }^{1}$ Bentuk dan sistem madrasah sebagai lembaga pendidikan Islam ini kemudian juga sampai di Indonesia, sehingga istilah tersebut juga berlaku di Indonesia, meskipun terdapat sedikit perbedaan.

Dalam sejarah dunia pendidikan Islam, madrasah menjadi istilah untuk menunjukkan suatu lembaga pendidikan secara umum, dimana di dalamnya terdapat proses pendidikan dan pengajaran yang cukup luas tanpa ada pengkhususan. Hal ini cukup berbeda dengan sejarah pendidikan Islam di Indonesia, dimana madrasah pada awal berdirinya dikhususkan hanya sebagai tempat pendidikan dan pengajaran agama. Di dalam madrasah pada waktu itu tidak diajarkan pengetahuan selain pengetahuan agama, bahkan madrasah dianggap sebagai lawan atau bentuk penolakan terhadap pendidikan umum. Hal inilah yang membedakan antara madrasah dalam dunia pendidikan Islam secara umum dan madrasah yang ada di Indonesia. Madrasah di tanah Arab ditujukan untuk semua sekolah seecara umum, sedangkan di Indonesia hanya ditujukan untuk sekolah yang mengajarkan pengetahuan agama, dan pada perkembangannya pada sekolah yang pengetahuan agama menjadi dasar atau ciri khasnya. ${ }^{2}$

Sejarah kelahiran dan perkembangan madrasah di Indonesia tidak bisa dilepaskan dari pesantren. Madrasah diyakini merupakan kelanjutan dari sistem pesantren yang telah dimodifikasi dan dikembangkan berdasarkan penyelenggaraan sekolah-sekolah umum dengan menggunakan sistem klasikal. ${ }^{3}$ Jika tidak demikian, ia merupakan hasil dari interaksi seorang terhadap dunia luar dan ketidakpuasan terhadap pola pengajaran yang berlangsung dalam sistem pesantren. Upaya yang dilakukan oleh kaum muslim Indonesia yang telah mendapatkan pengalaman di luar Indonesia untuk melakukan pembaharuan pendidikan Islam di Indonesia diwujudkan dalam bentuk lembaga madrasah. Semangat pembaharuan ini sedikit banyak disebabkan oleh terjadinya pembaharuan di dunia Islam di timur tengah pada waktu itu. Selain itu, umumnya madrasah juga lahir sebagai respon terhadap kebijakan dan sistem pendidikan pemerintah kolonial Belanda. ${ }^{4}$

Pemakaian istilah madrasah di Indonesia pertama kali digunakan oleh Abdullah Ahmad yang mendirikan Madrasah Adabiyah. Madrasah ini merupakan madrasah pertama yang menggunakan sistem klasikal yang ada di Indonesia. Perjuangan pembaharuan pendidikan Islam yang dilakukan oleh Abdullah Ahmad kemudian diikuti oleh beberapa organisasi Islam seperti

\footnotetext{
1 Ainurrofiq Dawam dan Ahmad Ta’arifin, Manajemen Madrasab Berbasis Pesantren, (Jakarta: Lista Fariska Putra, 2005), hal. 31.

${ }^{2}$ Haidar Putra Daulay, Historisitas dan Eksistensi Pesantren Sekolah dan Madrasah, (Yogyakarta, Tiara Wacana, 2001), hal. 59.

3 M. Ridlwan Nashir, Mencari Tipologi Format Pendidikan Ideal: Pondok Pesantren di Tengah Arus Perubahan, (Yogyakarta: Pustaka Pelajar, 2010), hal. 90.

${ }_{4}$ Ainurrofiq Dawam dan Ahmad Ta’arifin, Manajemen Madrasah..., hal. 34.
} 
PERTI, Al Irsyad, Muhammadiyah, Jami'atul Washilah dan yang lainnya. Masing-masing organisasi keagamaan dengan tokohnya masing-masing mengembangkan madrasah dengan corak yang tidak jauh berbeda di beberapa daerah. ${ }^{5}$ Bermunculannya madrasah di beberapa daerah tersebut juga menginspirasi KH. Hasyim Asy'ari yang diikuti KH. Wahid Hasyim dan KH. Ilyas untuk memperbaharui pola pendidikan di pesantren. Maka kemudian dibukalah madrasah di pondok pesantren Tebuireng dengan penambahan materi umum berhitung dan ilmu bumi. Pembaharuan yang dilakukan di pondok pesantren tersebut kemudian banyak diikuti oleh banyak pondok pesantren di daerah-daerah lain.

Madrasah di Indonesia diyakini mulai muncul pada awal abad ke 20 yang dilatarbelakangi oleh usaha pembaharuan pendidikan Islam serta ketidakpuasan dengan sistem pendidikan Islam yang ada. Selain itu, madrasah juga merupakan bentuk respon masyarakat muslim di Indonesia terhadap politik pendidikan Belanda. ${ }^{6}$ Meskipun lahir dalam kondisi sosial-politik yang terbatasi, madrasah tetap mampu berpartisipasi aktif dalam dunia pendidikan di Indonesia sampai saat ini. Kenyataan tersebut tidak muncul begitu saja, madrasah selalu berusaha menyesuaikan diri dengan berbagai keadaan yang ada.

Sejak pertama kali muncul sampai akhir abad ke 20, madrasah di Indonesia mengalami berbagai dinamika. Dinamika tersebutlah yang membawa madrasah menjadi lembaga pendidikan seperti yang kita lihat sekarang ini. Namun secara garis besar, dinamika yang dialami oleh madrasah - terutama yang berkaitan dengan perubahan dan perkembangan kurikulum - dapat dikelompokkan menjadi tiga periode, yaitu periode kemunculan sampai sebelum kemerdekaan, periode pasca-kemerdekaan, dan periode pasca-terbitnya SKB tiga menteri. Periode-periode tersebut menggambarkan madrasah pada masa pertumbuhan, masa perkembangan, serta penguatan eksistensi madrasah dalam dunia pendidikan di Indonesia.

\section{Dinamika Kurikulum Madrasah Berbasis Pesantren Pada Abad ke-20}

Munculnya madrasah di Indonesia merupakan fenomena baru pada abad 20 dan bukan merupakan kelanjutan atau adopsi model madrasah yang ada di Timur Tengah pada abad pertengahan. ${ }^{7}$ Dalam dunia pesantren, lahirnya madrasah sangat kuat dipengaruhi oleh pembaharuan yang terjadi di timur tengah, yang semnagatnya dibawa oleh orang Indonesia yang belajar disana. Semangat pembaharuan tersebut juga dapat ditemukan dari majalah atau surat kabar yang menggelorakan pembaharuan dalam Islam. Selain semangat pembaharuan tersebut, lahirnya madrasah dalam dunia pesantren juga

\footnotetext{
${ }^{5}$ Lihat Karel A. Steenbrink, Pesantren Madrasah Sekolab; Pendidikan Islam dalam Kurun Modern, (Jakarta: LP3ES, 1994), hal. 26-83.

${ }^{6}$ Maksum, Madrasab Sejarah dan Perkembangannya, (Jakarta: Logos Wacana Ilmu, 1999), hal. 82.

${ }^{7}$ Ibid., hal. 7.
} 
dipengaruhi oleh kebijakan pendidikan belanda yang mulai manarik minat kalangan pribumi. Pesantren sebagai basis pendidikan Islam masyarakat Indonesia meresponnya dengan mendirikan lembaga pendidikan yang hampir menyerupai lembaga pendidikan Belanda, namun dari sisi kurikulum berbeda.

Usaha agar para calon santrinya tidak berpaling dari pesantren dilakukan para kyai pesantren dengan mendirikan lembaga yang mirip dengan sekolah Belanda. Dalam batas-batas tertentu, bahkan madrasah dapat dikatakan sebagai lembaga pesekolahan ala Belanda yang diberi muatan keagamaan, atau bahkan kurikulumnya secara umum adalah materi keagamaan. ${ }^{8}$ Hal ini secara tidak langsung memang menggambarkan adanya perang pengaruh antara sekolah umum yang dimotori oleh Belanda dengan pesantren dan madrasah yang diperjuangkan oleh para kyai. Perang pengaruh tersebut selanjutnya menjadi stigma dalam masyarakat tentang dikotomi madrasah dan sekolah, tentang pendidikan agama dan pendidikan umum, yang bahkan masih bertahan sampai sekarang.

Sejak awal memang terdapat perbedaan orientasi antara sekolah dan madrasah. Perbedaan tersebut tampak salah satunya pada kurikulum yang diajarkan. Meskipun tidak dapat dipungkiri bahwa madrasah yang lahir dari pesantren sedikit banyak mencontoh pola kelembagaan yang ada dalam sekolah Belanda," namun dari aspek kurikulum madrasah secara tegas menjadikan pendidikan agama sebagai pokok pendidikannya. Sikap ini tampak pada masamasa berikutnya ketika situasi sosial-politik terus berubah, dimana madrasah tetap memperjuangkan prinsip awalnya untuk menjadi lembaga pendidikan yang mengajarkan pendidikan agama.

Secara umum, dinamika yang dilalui oleh madrasah - utamanya berkaitan dengan kurikulum - sebagaimana dijelaskan sebelumnya, dibagi menjadi tiga periode. Pada masing-masing periode tersebut terjadi pergolakan atau bahkan perubahan besar dalam hal kurikulum madrasah yang menentukan arah perkembangan madrasah hingga sampai pada bentuk yang sekarang ini. Periodeperiode tersebut secara lebih detail akan dijelaskan sebagai berikut:

\section{Periode Pertumbuhan; Dari Kelahiran Sampai Sebelum Kemerdekaan Indonesia}

Lahirnya madrasah di lingkungan pesantren memang terhitung lebih akhir dari pada madrasah-madrasah yang lainnya seperti Madrasah Adabiyah yang didirikan oleh Abdullah Ahmad pada tahun 1909 atupun Diniyah School (Madrasah Diniyah) yang didirikan pada tahun 1915 oleh Zainudin Labai alYunusi. Di kalangan pesantren, madrasah mulai dikenal dan meluas pertama kali

\footnotetext{
8 Ibid., hal. 93.

${ }^{9}$ Lihat Karel A. Steenbrink, Pesantren...., hal.
} 
pada tahun 1929 ketika KH. Moh. Ilyas diberi tugas menjadi pengawas umum dan pemimpin pesantren salafiyah setelah ia lulus dari HIS. Dengan persetujuan KH. Hasyim Asy'arie, KH. Moh. Ilyas memasukkan mata pelajaran umum seperti membaca dan menulis huruf latin, ilmu bumi, sejarah serta bahasa melayu. ${ }^{10}$ Bersama sepupunya yang juga merupakan putra KH. Hasyim Asy'arie - KH. Wahid Hasyim -, KH. Moh. Ilyas melakukan terobosan yang benarbenar baru dalam lingkungan pesantren dengan memasukkan mata pelajaran umum dalam madrasah yang sebelumnya hanya mengajarkan pelajaran agama. ${ }^{11}$

Sebelumnya, madrasah salafiyah yang didirikan pada tahun $1919^{12}$ oleh KH. Hasyim Asy'arie hanya khusus mengajarkan pelajaran agama. Madrasah dalam lingkungan pesantren pada batas-batas tertentu juga telah ada sejak tahun 1915, ketika KH. Wahab Hasbullah bersama dengan KH. Mas Manshur mendirikan madrasah taswirul afkar. ${ }^{13}$ Dalam madrasah-madrasah ini hanya diajarkan pelajaran agama, khususnya pengajaran al-Qur'an, namun dengan menggunakan sistem klasikal. Pada periode ini, madrasah dalam lingkungan pesantren umumnya masih hanya mengajarkan pelajaran agama, akan tetapi dari segi sistem dan metode sudah ada perubahan dari metode sebelumnya.

Hal ini sedikit berbeda dengan madrasah-madrasah yang berdiri di luar lingkungan pesantren. Madrasah-madrasah tersebut pada umumnya telah memasukkan pelajaran umum, atau bahkan didominasi oleh pelajaran umum. Sebagai contoh, Madrasah Adabiyah di Padang yang didirikan oleh Abdullah Ahmad pada tahun 1909. Dalam madrasah ini, perubahan radikal dilakukan oleh Abdullah Ahmad dari sistem surau. Ia merasa tidak puas dengan pengajaran pada surau dan kemudian mengubahnya dengan sistem madrasah yang mata pelajarannya banyak terdiri dari pata pelajaran umum, sedangkan pelajaran agama hanya diberkan selama 2 jam perminggu. Sistem tersebut cukup diterima di Padang, sedangkan di tempat sebelumnya yang juga pernah ia dirikan madrasah - Padang Panjang -, sistem tersebut di tolak sehingga terpaksa madrasah tersebut ditutup. Perubahan yang dilakukan Abdullah Ahmad ini berbeda dengan perubahan yang dilakukan oleh Zainuddin Labay. Perubahan dilakukan Zainuddin Labay secara halus dari sistem surau, dengan mendirikan Madrasah Diniyah yang di dalam kurikulumnya terdapat pelajaran umum seperti sejarah dan ilmu bumi. ${ }^{14}$

Sampai pada tahun 1930, kurikulum yang digunakan dalam madrasah pada umumnya masih berorientasi pada pelajaran agama, terutama pada madrasah

\footnotetext{
10 Selain mata pelajaran yang telah disebutkan di atas, di Madrasah Salafiyah juga telah diajarkan ilmu hitung. Lihat Zuhairini, Dkk., Sejarah Pendidikan Islam, cet. 9, (Jakarta: Bumi Aksara, 2009), hal. 222.

11 Ibid., hal. 70.

12 Dalam versi lain disebutkan madrasah salafiyah didirikan pada tahun 1916. Lihat Karel Steenbrink, Pesantren....., hal. 70 .

${ }^{13}$ Haidar Putra Daulay, Historisitas......, hal. 64.

${ }^{14}$ Karel Steenbrink, Pesantren....., hal. 38-44.
} 
yang berbasis pada pesantren. Keadaan ini sedikit banyak juga dipengaruhi oleh kebijakan Belanda yang cukup ketat mengawasi perkembangan pendidikan Islam. Mereka khawatir misi eksploitasi dan kristenisasi yang dilancarkan akan terhalangi sebab perkembangan pendidikan Islam, terutama madrasah. ${ }^{15}$ Keadaan semacam ini berlangsung sampai berakhirnya pendudukan Belanda di bumi Nusantara. Meski demikian madrasah tetap mampu memperahankan keberadaannya, dan sebagian darinya mampu berkembang menjadi lebih baik. Hal ini dapat dilihat pada periode setelah tahun 1930, dimana mulai banyak madrasah yang memasukkan mata pelajaran umum dalam kurikulumnya. ${ }^{16}$

Dinamika kurikulum madrasah pada periode ini tidak berjalan seragam. Masuknya mata pelajaran umum dalam kurikulum madrasah terjadi secara tidak merata, dan dalam lingkup madrasah yang berbasis pada pesantren perkembangannya cukup lambat karena masih banyak kalangan yang belum bisa menerima kehadiran sistem yang baru tersebut. Prosentase kurikulum madrasah yang membedakan antara pelajaran umum dan pelajaran agama pada waktu itu sangat beragam, dari 30:70 sampai dengan 70:30. Selain itu, dari sisi penjenjangan dan lamanya belajar, sistem madrasah pada periode ini juga masih sangat beragam. ${ }^{17} \mathrm{Hal}$ ini terjadi karena pada periode ini belum ada standarisasi yang mengatur tentang madrasah. Perkembangan yang terjadi merupakan hasil dari improvisasi dan kebijakan yang dilakukan oleh pengelola tiap-tiap madrasah yang bersangkutan.

Berbeda dengan Belanda, kebijakan pendidikan Islam yang diterapkan oleh Pemerintahan Jepang dapat dikatakan sedikit lebih longgar. Hal ini tentu memberikan keuntungan bagi perkembangan pendidikan Islam, salah satunya dalam diri madrasah. Pada masa tersebut, madrasah dikembangkan secara massif untuk mamanfaatkan kesempatan yang ada dari kebijakan Jepang. Situasi tersebut labih menguntungkan lagi bagi madrasah yang berada dalam lingkungan pesantren yang tidak mendapatkan pengawasan secara langsung dari pemerintah Jepang. ${ }^{18}$ Memang tidak terdapat laporan yang pasti terkait perkembangan kurikulum yang terjadi pada masa pemerintahan Jepang ini, namun kemungkinan besar yang terjadi dari aspek kurikulum juga berkembang secara massif. Kemungkinan tersebut dapat dilihat dari keadaan kurikulum sebelum Jepang berkuasa dan setelah kemerdekaan Indonesia, yang menampilan perbedaan yang cukup jauh.

\footnotetext{
${ }^{15}$ Hasbullah, Sejarah Pendidikan Islam di Indonesia Lintasan Sejarah Pertumbuban dan Perkembangan, (Jakarta: Raja Grafindo Persada, 1996), hal. 61.

${ }^{16}$ Haidar Putra Daulay, Historisitas......, hal. 65.

${ }^{17}$ Ibid., hal. 73.

${ }^{18}$ Hasbullah, Sejarah Pendidikan......., hal. 70.
} 


\section{Periode Perkembangan; Madrasah Pasca-Kemerdekaan Indonesia}

Tidak jauh setelah kemerdekaan Indonesia diraih, pemerintah Indonesia mendirikan Departemen Agama yang salah satu bidang garapannya adalah pendidikan Islam. Secara politik, Departemen Agama inilah yang mempunyai otoritas untuk memperjuangkan Pendidikan Islam dalam ranah kebijakan pemerintah. Dalam posisi demikian, Departemen Agama merupakan representasi dari umat Islam Indonesia dalam memperjuangkan pendidikan Islam secara lebih luas.

Kemerdekaan yang diraih Indonesia menjadikan kendali kebijakan tidak lagi dipegang oleh kaum kolonial, tetapi beralih ke tangan bangsa Indonesia sendiri. Keadaan yang demikian tersebut menjadikan pemerintah Indonesia bebas menentukan kebijakan yang dirasa sebagai kebutuhan masyarakat. Pendidikan menjadi bagian penting yang dirasa menjadi kebutuhan masyarakat dan Indonesia pada saat itu, dan ketika itu lembaga pendidikan yang ada umumnya adalah sekolah warisan kolonial dan madrasah yang menjadi basis pendidikan umat Islam. Meskipun secara sosial-politik keadaan belum sepenuhnya stabil, pemerintah Indonesia tetap menguasahakan proses pendidikan bagi masyarakatnya yang sesuai dengan cita-cita negara. Hal itu dibuktikan dengan didirikannya Departemen P\&K dan Departemen Agama yang masing-masing memiliki fokus garapan pada bidang pendidikan. Dengan berbagai dinamika yang terjadi, kedua departemen ini berkolaborasi dalam bidang pendidikan di Indonesia. ${ }^{19}$

Pada periode ini, pola pendidikan diarahkan pada proses konvergensi dan atau kolaborasi antara sekolah dengan madrasah. Hal ini dapat dilihat dari dimasukannya pelajaran agama pada sekolah umum dan pelajaran umum di madrasah yang diprakarsai oleh Departemen P\&K dan Departemen Agama. Proses tersebut belum ditemukan pada lembaga pendidikan sebelumnya yang secara umum hanya satu bidang saja yang digarap, atau kalaupun sudah ada, skalanya sangat terbatas seperti di madrasah.

Perkembangan madrasah pada periode ini awalnya berjalan beriringan dengan sekolah umum sebagai upaya pemerintah memajukan pendidikan di Indonesia. Namun upaya tersebut belum sepenuhnya diterima oleh masyarakat, khususnya yang mengelola madrasah. Hal ini menjadikan madrasah pada periode ini belum memiliki format yang sama, walaupun secara resmi pemerintah telah mengeluarkan kebijakan sebagai pengakuan formal terhadap madrasah.

Dari sisi jenjang, pemerintah telah menetapkan jenjang pendidikan madrasah berdasarkan Peraturan Menteri Agama Nomor 1 tahun 1946 dan disempurnakan dengan Peraturan Menteri Agama No. 7 Tahun 1952. Ketentuan dalam peraturan tersebut menyebutkan jenjang pendidikan madrasah berupa

${ }_{19}$ Zuhairini, Dkk., Sejarah Pendidikan Islam, cet. 9, (Jakarta: Bumi Aksara, 2008), hal. 153-154. 
ibtidaiyah, tsanawiyah dan aliyah. ${ }^{20}$ Sedangkan dari sisi kurikulum, pemerintah pernah mengeluarkan kebijakan berupa Madrasah Wajib Belajar yang kurikulumnya berupa mata pelajaran agama sebesar yang prosentasenya $25 \%$, serta mata pelajaran umum dan keterampilan yang prosentasenya sebesaar $75 \%$. Penguasaan keterampilan difokuskan pada bidang ekonomi, industrialisasi, dan transmigasi sebagai bekal anak didik setelah ia tamat belajar. ${ }^{21}$ Namun kebijakan ini tidak berjalan sesuai harapan, yang salah satu sebabnya adalah tanggapan yang kurang dari masyarakat dan penyelenggara madrasah. ${ }^{22}$

Hal tersebut menandakan masih belum menyatunya masyarakat dan penyelenggara madrasah dengan pemerintah yang memiliki otoritas kebijakan. Keadaan ini menyebabkan tidak seragamnya format madrasah, terutama dari aspek kontent kurikulumnya. Berbagai usaha dilakukan oleh Departemen Agama, terutama untuk memancing pesantren mengikuti model madrasah yang dikonsep oleh pemerintah atau mendirikan madrasah dengan model yang ditawarkan pemerintah. Untuk menguatkan daya tarik, pemerintah akan memberikan bantuan pendidikan kepada madrasah yang mau mengikuti kehendak Departemen Agama, yaitu dengan memperhatikan pendidikan umum dalam madrasah. ${ }^{23}$

Usaha pemerintah tersebut cukup membuahkan hasil, dengan banyaknya madrasah di lingkungan pesantren yang dinegerikan atau sekedar mengikuti pola yang ditawarkan oleh pemerintah. Meskipun belum mampu menjangkau semua pesantren, namun banyaknya pesantren yang mulai membuka diri terhadap pola baru ini sudah merupakan progres yang bagus dari usaha pemerintah.

Secara umum, bila kita melihat lembaga madrasah - khususnya yang berada dalam lingkungan pesantren -, pada tahun 1945-1975 kurikulum pendidikan yang dipakai masih berorientasi pada pelajaran agama. ${ }^{24}$ Itulah sebabnya mengapa Departemen Agama sebagai lembaga yang memiliki kewenangan menaungi dan mengembangkan madrasah melakukan upaya yang keras agar eksistensi madrasah semakin diakui dengan cara memajukan pelajaran umum dalam madrasah. Pada periode tersebut, pendidikan umum di madrasah dianggap tidak akan mampu mencapai tingkat yang sama dengan sekolah umum. Anggapan itulah yang oleh Departemen Agama berusaha dihilangkan dengan membuat rumusan kurikulumnya sepertiga berupa pelajaran agama dan sisanya berupa pelajaran umum. ${ }^{25}$

\footnotetext{
${ }^{20}$ Haidar Putra Daulay, Historisitas......, hal. 75.

21 Ibid., hal. 76.

22 Ibid., hal. 78.

${ }^{23}$ Karel Steenbrink, Pesantren....., hal. 97.

24 Muhammad Nasir, "Kurikulum Madrasah: Studi Perbandingan Madrasah di Asia" Jurnal Pendidikan Islam Nadwa, volume 9, Nomor 2, 2015, hal 6.

25 Direktorat Jenderal Pendidikan Islam, "Sejarah Pendidikan Islam”, dalam www.pendis.kemenag.go.id. Diakses pada 16 Februari 2017 pada pukul 09.00 WIB.
} 
Anggapan miring yang dilayangkan kepada madrasah serta sering tidak dianggapnya peran madrasah dalam sistem pendidikan nasional membawa dampak negatif pada eksistensi madrasah. Meskipun hal tersebut sudah berusaha diredam oleh Departemen Agama, namun pada akhirnya tetap ada upaya untuk menghilangkan peran atau bahkan keberadaan madrasah dalam sistem pendidikan nasional. Pemerintah dalam hal ini berupaya melimpahkan peran Departemen Agama sebagai penaung madrasah kepada Departemen P \& K. Upaya ini dianggap sebagai satu upaya menghilangkan keberadaan madrasah karena Departemen P \& K dianggap kurang mampu dalam mengelola pendidikan keagamaan. ${ }^{26}$ Pro-Kontra terhadap upaya pemerintah ini cukup panjang, namun pada ujungnya polemik ini menempatkan madrasah pada posisi yang lebih baik pada sistem pendidikan nasional.

\section{Periode Penguatan Eksistensi; Pasca-Surat Keputusan Bersama (SKB) Tiga Menteri}

Pada sekitaran tahun 1970, kondisi pendidikan di Indonesia belum sepenuhnya mapan. Pada tahun tersebut, terjadi dikotomi keilmuan yang cukup mempengaruhi kondisi pendidikan di Indonesia. Anggapan masyarakat tentang dikotomi keilmuan tersebut kemudian coba diredam oleh pemerintah saat itu dengan keluarnya Kepres No. 34 tahun 1972 tentang penyatuan payung semua lembaga pendidikan dibawah naungan kementrian P\&K. Keputusan Presiden (Kepres) tersebut kemudian dikuatkan lagi dengan dikeluarkannya Inpres No. 15/1974 agar Kepres No. 34 Tahun 1972 segera direalisaikan. ${ }^{27}$ Penegasan dengan Inpres tersebut menandakan adanya polemik yang cukup membuat tidak dijalankannya Kepres yang berkaitan. Situasi ini menggambarkan ketegangan yang cukup keras antara madrasah dengan sistem pendidikan nasioal.

Sadar akan kebaratan dari masyarakat yang "mendukung" keberadaan madrasah, pemerintah kemudian mengeluarkan petunjuk pelaksanaan Kepres dan Inpres sebelumnya yang salah satu isinya menyebutkan pembinaan madrasah berada pada tanggung jawab Menteri Agama. Dari situ kemudian lahirlah SKB tiga menteri tentang "Peningkatan Mutu Pendidikan pada Madrasah" pada tahun $1975 .{ }^{28}$ Keluarnya SKB tiga menteri tersebut selain sebagai pengakuan terhadap eksistensi madrasah juga menjawab keresahan masyarakat akan dihapuskannya sistem madrasah. Dengan SKB tiga menteri tersebut, peran serta madrasah dalam mencerdaskan kehidupan bangsa mengarah pada pengakuan dan pengintegrasian ke dalam sistem pendidikan nasional.

Secara umum, kesejajaran antara madrasah dengan sekolah menjadi isi pokok SKB tiga menteri tersebut. Prasyarat yang harus dipenuhi sebuah

\footnotetext{
${ }^{26}$ Karel Steenbrink, Pesantren....., hal. 99.

${ }^{27}$ Maksum, Madrasah......., hal. 146-147.

28 Ibid., hal. 149.
} 
madrasah untuk mendapat pengakuan kesejajaran dengan sekolah umum adalah dengan memprosentasekan kurikulum sebesar 30\% untuk pelajaran agama dan $70 \%$ untuk pelajaran umum. Selain kesejajaran pada tingkatan (MI dengan SD, MTs dengan SMP dan MA dengan SMA), dalam SKB tiga menteri tersebut juga menetapkan hal-hal sebagai berikut: ${ }^{29}$

a. Ijazah madrasah mempunyai nilai yang sama dengan ijazah sekolah umum yang setingkat.

b. Lulusan madrasah dapat melanjutkan ke sekolah umum setingkat lebih di atasnya.

c. Siswa madrasah dapat berpindah ke sekolah umum setingkat.

d. Pengelolaan madrasah dan pembinaan mata pelajaran agama dilakukan menteri agama, sedangkan pengelolaan dan pembinaan mata pelajaran umum pada madrasah dilakukan oleh menteri P\&K, bersama-sama menteri agama dan menteri dalam negeri.

Demi menunjang keberlangsungan dan mendukung maksud yang tertuang dalam SKB tiga menteri pada tahun 1975, Departemen Agama menyusun kurikulum 1976 yang diberlakukan secara intensif sejak tahun 1978. ${ }^{30}$ Selanjutnya, Menteri Agama dan Menteri P\&K bekerjasama menyusun kurikulum bagi sekolah dan madrasah. Dari proses tersebut, lahirlah Surat Keputusan Bersama (SKB) Menteri Agama dan Menteri P\&K No. 0299/U/1984 untuk Departemen P\&K; 045/1984 untuk Departemen Agama tahun 1984 tentang pengaturan pembakuan kurikulum sekolah umum dan kurikulum madrasah. ${ }^{31}$ Bagi Departemen Agama, keputusan tersebut menjadi penyempurnaan kurikulum 1976 yang sebelumnya sudah dirancancang. Keputusan ini kemudian dikenal dengan kurikulum 1984, yang di dalamnya memuat kurikulum yang baku terutama bagi madrasah. Mata pelajaran agama mulai dari tingkat ibtidaiyah sampai dengan 'aliyah mulai diperinci dengan prosentase pada masing-masing tingkatan sebesar 30\%.

Pembakuan kurikulum dalam kurikulum 1984 ini menjadi langkah pendukung masuknya madrasah dalam sistem pendidikan nasional. Oleh pemerintah, madrasah yang mendapatkan "keuntungan" dari kebijakan ini hanya madrasah yang mau mengikuti pola yang ditetapkan oleh pemerintah. Kebijakan ini selanjutnya banyak menarik madrasah dalam lingkungan pesantren untuk mengikuti dan membuka diri dengan kebijakan pemerintah. Civil effect yang muncul dari kebijakan ini menjadi sebabnya, karena ijazah madrasah yang diakui oleh pemerintah hanya diperuntukkan bagi madrasah yang mengikuti kebijakan tersebut. Di lain pihak, para peserta didik dalam lingkungan pesantren mulai mempertimbangkan keberadaan ijazah, sehingga madrasah yang berada di

\footnotetext{
${ }^{29}$ Direktorat Jenderal Pendidikan Islam, "Sejarah Pendidikan Islam”, dalam www.pendis.kemenag.go.id.

${ }^{30}$ Maksum, Madrasah......., hal. 153.

31 Zuhairini, Dkk., Sejarah Pendidikan........, hal. 198.
} 
lingkungan pesantren harus mengikuti pola tersebut untuk tetap manarik minat calon santrinya.

Gelombang peralihan dalam diri madrasah nampak besar pada waktu itu bahkan bagi madrasah yang berada dalam lingkungan pesantren. Hal ini menimbulkan kekhawatiran dan keprihatinan akan kualitas pendidikan agama, terutama untuk mencetak generasi yang mempunyai pengetahuan keagamaan yang mendalam sebagai calon ulama yang tangguh. Madrasah yang berdasarkan SKB tiga menteri dan mengikuti kurikulum 1984 dikhawatirkan tidak memiliki modal yang cukup untuk menjadi ulama yang tangguh. Oleh karenanya, pemerintah melalui Departemen Agama membuka jalur baru pada tingkat 'aliyah yang disebut Madrasah Aliyah Program Khusus (MAPK). Prosentase kurikulum pada madrasah ini sebesar $70 \%$ untuk pelajaran agama dan 30\% untuk pelajaran umum. Madrasah ini bertujuan menyiapkan lulusan yang menguasai pengetahuan agama secara mendalam sehingga mempunyai kemampuan yang mumpuni dalam bidang agama. ${ }^{32}$

Perkembangan madrasah selanjutnya terjadi ketika terbit Undang-Undang Nomor 2 Tahun 1989 yang secara sah telah menempatkan madrasah dalam bagian sistem pendidikan nasional. Undang-Undang tersebut membicarakan pendidikan secara umum, namun ketentuan dan peraturan-peraturan yang mengatur keberadaan madrasah juga terbut dalam UU tersebut. berdasarkan peraturan tersebut, madrasah dari tingkat Ibtidaiyah sampai Aliyah memiliki kedudukan yang sama dengan sekolah umum. Perbedaannya terletak pada ciri khas Islam yang melekat dalam diri madrasah sebagai landasan pengakomodasian kepentingan keagamaan. ${ }^{33}$

Sebagai tindak lanjut dari UU Nomor 2 Tahun 1989 ini, pemerintah menyusun kurikulum baru sebagai penyempurnaan terhadap kurikulum sebelumnya. Kurikulum ini selanjutnya dikenal dengan kurikulum 1994. Secara umum, kurikulum ini tidak mempengaruhi jam pelajaran serta karakter pendidikan keagamaan siswa. Kurikulum ini dirancang hanya untuk menyesuaikan dengan kebijakan yang baru dan tidak terlalu bepengaruh terhadap pendidikan agama baik di sekolah maupun di madrasah. ${ }^{34}$

Secara umum pada periode ini pendidikan madrasah diarahkan pada bentuk yang seragam, baik dari sisi jenjang maupun kurikulum. Pada periode ini pula madrasah mengalami perubahan dari berbagai macam aspek, terutama pada aspek kurikulum yang memberikan madrasah tempat dalam sistem pendidikan nasional. Bahkan madrasah pada periode ini memiliki kesetaraan dengan sekolah umum, dimana siswa dan lulusannya diakui dan mendapatkan tempat yang sama

\footnotetext{
32 M. Ridlwan Nashir, Mencari Tipologi....., hal. 94-95. Lihat juga Direktorat Jenderal Pendidikan Islam, "Sejarah Pendidikan Islam", dalam www.pendis.kemenag.go.id.

33 A, Malik Fajar, Madrasah dan Tantangan Modernitas, (Bandung: Penerbit Mizan, 1988), hal. 33.

${ }^{34}$ Direktorat Jenderal Pendidikan Islam, "Sejarah Pendidikan Islam”, dalam www.pendis.kemenag.go.id.
} 
seperti sekolah umum. Kondisi tersebut berlangsung dan bertahan hingga saat ini dengan penyempurnaan-penyempurnaan yang diperlukan.

Namun demikian, bukan berarti eksistensi yang ditunjukkan madrasah semenjak SKB tiga menteri tersebut tanpa menimbulkan masalah. Meski secara kelembagaan madrasah telah menempati posisi yang "aman", namun di sisi lain madrasah seperti kehilangan - atau setidaknya kurang jelas - orientasinya. Posisi yang ditempati madrasah saat ini secara tidak langsung melemahkan atau bahkan mendangkalkan misi madrasah yang mempunyai ciri intrinsik keilmuan agama Islam. Selanjutnya, madrasah dengan kondisi yang sekarang tidak mampu melahirkan generasi yang secara kualitas keagamaan "mumpuni", dan pada gilirannya tidak akan mampu menyediaan tanaga ahli agama yang menyebabkan kesenjangan antara Islam dan pemeluknya. ${ }^{35}$ Pada kenyataannya sekarang, masalah inilah yang umumnya dihadapi oleh madrasah yang perlu mendapat perhatian secepatnya.

\section{Kesimpulan}

Keberadaan madrasah sebagai lembaga pendidikan Islam di Indonesia merupakan fenomena baru yang dimulai sejak awal abad ke-20. Pembaharuan dalam Islam dan ketidakpuasan dengan sistem yang ada pada waktu itu serta respon terhadap politik pendidikan kolonial menjadi sebab munculnya madrasah di Indonesia. Berbagai dinamika telah dilalui madrasah sejak pertama kali muncul, dan berkat kelenturannya dalam menyesuaiakan dengan kondisi sosialpolitik yang ada, madrasah mampu bertahan dan tetap eksis sampai saat ini.

Dari aspek kurikulum, dinamika yang dilalui madrasah setidaknya dapat dikelompokkan ke dalam tiga periode, yaitu periode pertumbuhan, periode perkembangan dan periode penguatan eksistensi. Pada periode pertumbuhan, kurikulum madrasah masih belum seragam, disesuaikan dengan orientasi kelompok atau orang yang mengelola madrasah. Namun pada umumnya, pelajaran agama menjadi pokok pelajaran pada madrasah pada periode ini. Pada periode perkembangan, terdapat upaya konvergensi dengan sistem sekolah, dimana madrasah diupayakan untuk mengikuti model sekolah dengan penyesuaian kurikulumnya. Sedangkan pada periode penguatan eksistensi, madrasah telah diakui eksistensinya oleh pemerintah dan sudah manjadi bagian dalam sistem pendidikan nasional. Namun konsekuensinya adalah keharusan madrasah untuk mengikuti pola yang ditawarkan pemerintah, dengan memasukkan secara lebih besar pelajaran umum dengan prosentase $70 \%$, sedangkan pelajaran agama hanya tinggal 30\% saja.

\footnotetext{
35 Muhammad Ahmad Sahal Mahfudh, "Madrasah Dari Masa ke Masa" dalam Nuansa Fiqh Sosial, cet. VII (Yogyakarta: LKiS, 2011), hal. 293-294.
} 


\section{Daftar Pustaka}

Daulay, Haidar Putra, 2001, Historisitas dan Eksistensi Pesantren Sekolah dan Madrasah, Yogyakarta, Tiara Wacana.

Dawam, Ainurrofiq, dan Ahmad Ta'arifin, 2005, Manajemen Madrasab Berbasis Pesantren, Jakarta: Lista Fariska Putra.

Direktorat Jenderal Pendidikan Islam, "Sejarah Pendidikan Islam", dalam www.pendis.kemenag.go.id.

Fajar, A. Malik, 1988, Madrasab dan Tantangan Modernitas, Bandung: Penerbit Mizan.

Hasbullah, 1996, Sejarah Pendidikan Islam di Indonesia Lintasan Sejarah Pertumbuhan dan Perkembangan, Jakarta: Raja Grafindo Persada.

Mahfudh, Muhammad Ahmad Sahal, 2011, "Madrasah Dari Masa ke Masa" dalam Nuansa Fiqh Sosial, cet. VII Yogyakarta: LKiS.

Maksum, 1999, Madrasah Sejarah dan Perkembangannya, Jakarta: Logos Wacana Ilmu.

Nashir, M. Ridlwan, 2010, Mencari Tipologi Format Pendidikan Ideal: Pondok Pesantren di Tengah Arus Perubahan, Yogyakarta: Pustaka Pelajar.

Nasir, Muhammad, 2015, "Kurikulum Madrasah: Studi Perbandingan Madrasah di Asia" Jurnal Pendidikan Islam Nadwa, Volume 9, Nomor 2.

Steenbrink, Karel A., 1994, Pesantren Madrasah Sekolah; Pendidikan Islam dalam Kurun Modern, Jakarta: LP3ES.

Zuhairini, Dkk., 2008, Sejarah Pendidikan Islam, cet. 9, Jakarta: Bumi Aksara. 
16 | TADBIR : Jurnal Studi Manajemen Pendidikan, Vol. 3, No. 1, Mei 2019

This page belongs to the TADBIR : Jurnal Studi Manajemen Pendidikan

TADBIR : Jurnal Studi Manajemen Pendidikan vol. 3 , no. 1, Mei 2019

IAIN Curup - Bengkulu | p-ISSN 2580-3581; e-ISSN 2580-5037 